\title{
The Impacts of Social Responsibility on Enterprise Performance in Chinese Hospitality Industry
}

\author{
Ye Feng \\ School of Economics and Management, \\ Zhuhai City Polytechnic \\ Zhuhai 519000, China \\ Email: fengy1001@163.com
}

\author{
Yujie Chen \\ Faculty of Hospitality and Tourism Management, \\ Macau University of Science and Technology, \\ Taipa, Macau \\ Email: yjchen@must.edu.mo
}

\begin{abstract}
This study has investigated the relationship between corporate social responsibility (CSR) and corporate performance in the Chinese hospitality industry. We used several indicators to measure corporate performance and employed social contribution value per share (SCV) to calculate CSR. By using unbalanced panel data from all Chinese listed hospitality companies and employing a multiple regression analysis, we found that CSR has a negative relationship with short-term performance and a positive relationship with long-term performance. The result reminds us not to just focus on traditional performance indexes. In this research on corporate social responsibility, it is more realistic and practical to use longterm performance index as the dependent variable than shortterm indicator.
\end{abstract}

Keywords-Corporate social responsibility; Corporate performance; Hospitality industry; Chinese

\section{INTRODUCTION}

In response to the deteriorating international economic environment and expanding domestic demand, the Chinese government is focusing on the development of sunrise industries like hospitality and tourism. In their hospitality industry development report (2018) they noted that by the end of 2017 the number of hospitality companies increased by $6.69 \%$ over the previous year but profitability decreased by $90.4 \%$. While the industry is expanding, companies are challenged with improving competitiveness and profitability. Many have begun to build environmentally friendly operations and increase energy efficiency to reduce costs and improve profits. They are also paying more attention to employees, consumers, and commercial partners who can help them to develop competitive advantage. Corporate social responsibility (CSR) is playing an increasingly prominent role in the Chinese hospitality industry.

Davis (1973) [1] defines CSR as "the firm's consideration of and response to issues beyond the narrow economic, technical and legal requirements of the firm to accomplish social benefits along with the traditional economic gains which the firm seeks". Wahba \& Elsayed (2014) [2] noticed that firms can develop a competitive edge over rivals by investing in social responsibility. In the hospitality industry Bevan et al., (2004) [3] identified potential benefits such as the enhancement of profit, customer service, brand value, and long-term sustainability. However, Jones et al. (2006) [4] found a negative relationship between CSR and company financial performance (CFP). Peng \& Yang (2014) [5] suggested that investment in CSR diverts funds away from production.

Researchers have found that relationships between CSR and CFP are often idiosyncratic (Banerjee et al. 2003 [6]; Salzmann et al. 2005 [7]), implying that each major industry must find its own relationship, and not blindly apply the findings of other industries. We have collected unbalanced panel data from Chinese listed companies from 1992 to present and we found that the relationships between CSR and concentration are positively related to long-run endogenous growth. To add to social responsibility literature, this study was designed in the following ways.

It has focused on the hospitality industry because different industries present idiosyncratic relationships between CSR and company performance (Henriques \& Sadorsky, 1996 [8]; Lankoski, 2000 [9]; Salzmann et al., 2005 [10]). It sampled the emerging market in China, whereas much of the existing research evidence has been taken from developed countries.

It used sustainable growth rate as a dependent variable to measure CFP and represent self-development ability. For stakeholders market performance and capacity for internal sustainable development are very important.

We introduced an index-social contribution value per share $(\mathrm{SCV})$ as an independent variable to represent CSR. This official index was issued by the Shanghai Stock Exchange (SSE) in 2008 and is now promoted to all listed Chinese companies. It provides better CSR information to all stakeholders and gives them a clearer understanding of the real value created by the company.

This paper is organized as follows. The second section builds hypotheses and covers variable definition, statistical methods, data collection. The third section analyzes empirical results and discusses findings, and we conclude in section four. 


\section{METHOD}

\section{A. Proposed hypotheses}

As our Chinese economy expands people are paying more attention to company contributions to social stability and sustainable development. To win society's respect, many companies have enhanced their social coordination, and environmental policy and practice.

Sheldon (1923) first proposed CSR as a concept which does not just maximize profits but also considers ethical aspects. The modern CSR concept dates back to the 1950s and has evolved (Carroll, 1999) [11]. Carroll (1979) [12] believed that CSR refers to society's expectations for enterprises with respect to their economic, legal, ethical and philanthropic responsibilities. In recent years, hospitality companies have practiced CSR extensively (Robson \& Robson, 1996 [13]; Byrd, 2009 [14]). The hospitality literature has investigated various CSR issues (Kang et al., 2010 [15]; Kim et al., 2017 [16]) such as the financial impacts of socially responsible activities and their internal consequences.

While the relationship between CSR and corporate performance has been widely researched, the empirical evidence has provided mixed results, showing positive, negative, curvilinear and no effects. The mixed empirical results may be attributable to different model specifications, variables measurements, sample selection techniques and theoretical perspectives.

Enterprises live in the market and society simultaneously. There is the contractual relationship between enterprise and society. Society supports the company and demands that the company is socially responsible. The key in this contractual relationship is the stakeholder (Jiang \& Gu, 2008 [17]). On the other hand, Coase (1937) noted that there were transaction costs. Jones (1995) [18] argued that increasing CSR will improve the relationship with stakeholders and reduce transaction costs. Similarly Barnett (2007) [19] found that increasing CSR improves trustworthiness, thereby reducing transaction costs. In the hospitality industry researchers have identified a range of potential benefits such as the enhancement of profit, customer service, brand value, and long-term sustainability (Bevan et al., 2004) [20].

$\mathrm{H} 1$ : Corporate social responsibility has a positive effect on short-term financial performance.

$\mathrm{H} 2$ : Corporate social responsibility has a positive effect on long-term financial performance.

\section{B. Research Methodology}

\section{1) Variables Definition}

\section{a) Enterprise Performance}

Financial performance refers to a company's ability to generate new resources from day-to-day operations over a given time frame, and is gauged by net income and cash from operations. Nowadays stakeholders focus on market performance and capacity for internal sustainable development. This study uses ROE to measure short-term profitability and SGR (sustainable growth rate) to represent long-term selfdevelopment ability. ROE is net profit divided by average shareholder equity. SGR is the annual percentage of increase in sales that is consistent with a defined financial policy (Higgins, 1977) [21].

\section{b) Corporate Social Responsibility}

In our article, CSR was measured by using the social contribution value per share (SCV). Since 2006 in China, CSRC, SASAC, SSE and SZSE have released guidelines, requiring that listed companies issue regular social responsibility reports. In May 2008, the Shanghai Stock Exchange (SSE) issued the "Notice of Improving Listed Companies' Assumption of Social Responsibilities", to introduce the concept of "social contribution value per share" (SCV). This index calculates the added value created for the society by adding tax revenues created for the State, salary paid to employees, loan interest paid to creditors including banks, donations and other value for stakeholders, and deducting social costs of environmental pollution and other factors. It provides good information about the real value created by a company for all of its stakeholders, is widely used by listed companies in Shanghai and Shenzhen stock exchanges, and has become an important index in Chinese research literature.

\section{c) Control Variables}

This study controls several variables to define the relationship between dependent and independent variables. $\mathrm{LnA}$ is the natural logarithm of the number of years that the company has been listed. Leverage is the ratio of total liability over total assets. Total asset turnover is the ratio of operating revenue to average total assets.

\section{2) Statistical Methods}

When employing the panel data model, three alternatives were pooled: ordinary least square (OLS) regression model, fixed effect (FE) regression model, and random effect (RE) regression model. When the likelihood test was conducted, the $\mathrm{FE}$ regression model was more appropriate. When the Hausman test was done, the RE regression model was more suitable. Otherwise, the OLS regression model could have been used. However, if both the likelihood and Hausman tests are completed (in this paper the number of firms was greater than the number of years), the FE model is more suitable if panel data is not randomly sampled (Hausman, 1978). Conversely, the RE model is more appropriate if panel data is randomly sampled. In addition, since the panel data in the case study has the characteristic of $\mathrm{N}$ (the number of firms) $>\mathrm{T}$ (the number of years), the problems of serial correlation and panel unit root may be reasonably ignored.

\section{3) Data collection}

The study used unbalanced panel data consisting of all Chinese firms listed on the Shanghai Stock Exchange and Shenzhen Stock Exchange Limited from 1992 to 2015, and has excluded companies that received special treatment, had incomplete data, or extreme values (China Stock Market and Accounting Research Database; GTA). We have used a large sample and a longer period to ensure reliability and to reduce measurement error. The sample selection was guided by data availability. Our sample has included all listed hospitality industry firms based on the China Securities Index Co., Ltd's 
recommendation L124/36. In this article, we used STATA analysis software to process data, and tested four hypotheses.

\section{RESULTS}

This study has employed the panel data regression model to analyze the relationship between corporate social responsibility and corporate performance in China. In examining the repeated cross-section of observations, panel data are better suited to study the dynamics of change (Gujarati, 2003) [22]. We tested the impacts of corporate social responsibility on firm performance separately and report the evidence in Table 1.

TABLE I PANEL DATA REGRESSIONS OF FIRM PERFORMANCE

\begin{tabular}{|l|l|l|}
\hline Dependent variables & Model1 & Model2 \\
\hline \multirow{2}{*}{ Independent variables } & ROE & SGR \\
\cline { 2 - 3 } & FE coef. & RE coef. \\
\hline SCV & $-0.4193^{* * *}$ & $0.0958^{*}$ \\
\hline $\ln \mathrm{A}$ & $0.4764^{* *}$ & 0.08176 \\
\hline Lev & $1.3587^{* * *}$ & $-0.2767^{*}$ \\
\hline TAT & $0.5750^{*}$ & -0.0000 \\
\hline Constant & -0.9284 & -0.9421 \\
\hline R2 & 0.1075 & 0.0368 \\
\hline Fa & $5.78^{* * *}$ & \\
\hline Hausman Testb & $15.80^{* * *}$ & 4.62 \\
\hline BP-LM testc & & 0.00 \\
\hline
\end{tabular}

Note a: F test provides a test of the pooled OLS model against the fixed effects model based on the OLS residuals

Note b: Hausman test is the Hausman (1978) specification test for fixed effects over random effects

Note c: BP-LM test is one basic test for the relevance of random effects to be incorporated in a panel model proposed by Breusch/Pagan (1980). It tests for OLS over random effects.

$$
\text { Note } \mathrm{d}: * \mathrm{p}<0.1 \quad * * \mathrm{p}<0.05 \quad * * * \mathrm{p}<0.01
$$

Model 1 reveals the negative relationships between SCV and economic performance. The result is contrast with hypothesis 1 . While model 2 reveals the SCV positive impact on SGR, consistent with the hypothesis 2, saying that longterm corporate performance will increase as social responsibility strengthens. Therefore, we can infer the impacts of corporate social responsibility on firm performance vary with the different focuses of performance indexes. ROE emphasizes the short-term profitability from the owners' view. Social responsibility needs to balance the benefits to all business stakeholders. Consequently in some degree increasing CSR might have a negative effect on owners' current interests. However in the long run, CSR promotes the enterprises' endogenous growth (self-sustainable growth rate). Similarly Hart \& Ahuja found that investing in social responsibility initiatives is likely to lead to considerable costs in the short term (Hart \& Ahuja, 1996) [23] but the market often responds in the long-term (Shank et al., 2005) [24]. When investors prefer near-term earnings, the short-term performance cycles discourage them from supporting long-term projects (Koh, 2003) [25]. To sum up, CSR has a positive impact on longterm sustainable growth, but negative effects on short-term financial profits in Chinese hospitality listed companies. Hypothesis 1 isn't supported by model 1 but hypothesis 2 is supported by model 2, which means CSR has a positive influence on long-term performance and a negative influence on short-term performance. The outcome reminds us not to just focus on traditional performance indexes. In this research about corporate social responsibility, it is more realistic and practical to use the sustainable growth rate (SGR) as the dependent variable than ROE.

\section{CONCLUSIONS}

The objective of this study was to analyze whether social responsibility is related to Chinese hospitality company performance, and to analyze the impact of the variable on financial performance. We found that SCV (Social Contribution Value per Share) is positively related to sustained growth, and CSR promotes long-run endogenous growth. Hospitality industry firms have opted to take on more social responsibility to increase performance and strengthen marketing competitiveness.

The hospitality industry has the potential for long-run economic growth. In China many provinces are promoting green tourism by offering policy support. To benefit from these policies and increase corporate performance, a lot of hospitality companies try to fulfill their corporate social responsibility and benefit stakeholders. To improve social responsibility hospitality firms should consider the interests of all stakeholders (customers, suppliers, employers, government, and the environment) when making decisions. Ignoring key stakeholders may damage financial performance.

Finally, this study has some limitations related to the small number of firms included in the analysis. These limitations can be attributed to the low number of publicly listed tourism hospitality firms in the stock exchanges that we considered. The hospitality firms in this study represent $8 \%$ of all nonfinancial listed firms. Further analysis of unlisted hospitality firms may be warranted. However, finding the required 
financing data for these firms will be challenging. We argue that this study sheds light on the importance of social responsibility activities within the hospitality industry in Chinese emerging markets and provides a basis for other related studies.

\section{REFERENCE}

[1] Davis, K. (1973). The case for and against business assumption of social responsibilities. Academy of Management Journal, 16(2), 312322.

[2] Wahba, H., \& Elsayed, K. (2014). The effect of institutional investor type on the relationship between CEO duality and financial performance. International Journal of Business Governance and Ethics, 9(3), 221-242.

[3] Bevan, S., Isles, N., Emery, P., \& Hoskins, T. (2004). Achieving high performance: CSR at the heart of business. London: The Work Foundation.

[4] Jones, Peter. Comfort, Daphne. Hillier, David. (2006). Corporate social responsibility and the UK construction industry. Journal of Corporate Real Estate. 8(3), 134-150.

[5] Chih-Wei Peng, Mei-Ling Yang. (2014). The Effect of Corporate Social Performance on Financial Performance: The Moderating Effect of Ownership Concentration. Journal Business Ethics,2014(123):171-182.

[6] Banerjee, S. B., Iyer, E. S., Kashyap, R. K. (2003). Corporate environmentalism: Antecedents and influence of industry type. Journal of Marketing, 67, 106-122.

[7] Salzmann, O., Steger, U. (2005). The business case for corporate sustainability: Literature review and research options. European Management Journal. 23, 27-36.

[8] Henriques, Irene. Sadorsky, Perry. (1996). The determinants of an environmentally responsive firm: an empirical approach. Journal of Environmental Economics and Management. 30 (3), 381.

[9] Lankoski, Leena. (2000). Determinants of environmental profit: an analysis of the firm-level relationship between environmental performance and economic performance. Finland, Europe: Helsinki University of Technology, 2000. Finland, Europe: Teknillinen korkeakoulu, 2000.

[10] Salzmann, Oliver. Ionescu-somers, Aileen. Steger, Ulrich. (2005). The Business Case for Corporate Sustainability: Literature Review and Research Options. European Management Journal. 23(1), 27-36.

[11] Carroll, A. B. (1999). Corporate social responsibility: Evolution of a definitional con $\neg$ struct. Business \& Society, 1999(38): 268-295.

[12] Carroll. A.B. (1979). Three Dimensional Conceptual Model of Corporate Performance. Academy of Management Review 1979(10):499.

[13] Robson, Jane. Robson, Ian. (1996). From shareholders to stakeholders: critical issues for tourism marketers. Tourism Management 17(7), 533540.

[14] Byrd, L. S. (2009). Collaborative corporate social responsibility: A case study examination of the international public relations agency involvement in the United Nations Global Compact. Corporate Communications. 14(3),303-319.

[15] Kang, Kyung Ho. Lee, Seoki. Huh, Chang. (2010). Impacts of positive and negative corporate social responsibility activities on company performance in the hospitality industry. International Journal of Hospitality Management. 29(1),72-82.

[16] Kim, Hyelin Lina. Rhou, Yinyoung. Uysal, Muzaffer. Kwon, Nakyung. (2017). An examination of the links between corporate social responsibility (CSR) and its internal consequences. International Journal of Hospitality Management. 61, 26.

[17] Jiang Qijun, Guqingliang. (2008). Corporate Social Responsibility and Enterprise Strategy. Shanghai: Shanghai People's Publishing House (2008). 5-10.

[18] Jones, T. M. (1995). Instrumental Stakeholder Theory: A Synthesis of Ethics and Economics. Academy of Management Review, 20(2), 404437.
[19] Barnett, M. L. (2007). Stakeholder Influence Capacity and the Variability of Financial Returns To Corporate Social Responsibility. Academy of Management Review, 32(3), 794-816.

[20] Bevan, S., Isles, N., Emery, P., \& Hoskins, T. (2004). Achieving high performance: CSR at the heart of business. London: The Work Foundation.

[21] Higgins, R.C. (1977). How Much Growth Can a Firm Afford? Financial Management, 6 (3), 7-16.

[22] Gujarati, D.N., (2003). Basic Econometrics, fourth ed. McGraw-Hill, New York.

[23] Hart, S. L., \& Ahuja, G. (1996). Does it pay to be green? An empirical examination of the relationship between emission reduction and firm performance. Business strategy and the Environment, 5(1), 30-37.

[24] Shank, T., Manullang, D., Hill, R. (2005). Doing well while doing good revisited: A study of socially responsible firms' short-term versus long term performance. Managerial Finance, 31(8), 33-46.

[25] Koh, P. (2003). On the association between institutional ownership and aggressive corporate earnings management in Australia. The British Accounting Review, 35, 105-128. 